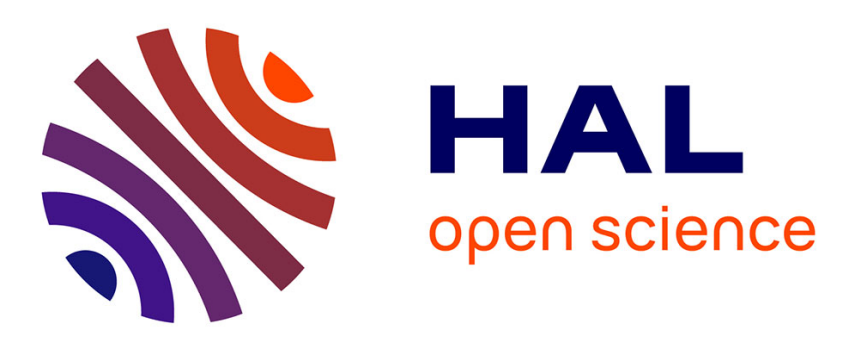

\title{
DIFFUSION AVANT ET ARRIÈRE D'IONS LOURDS ET MOMENTS ANGULAIRES COMPLEXES
}

\author{
N. Rowley, C. Marty
}

\section{To cite this version:}

N. Rowley, C. Marty. DIFFUSION AVANT ET ARRIÈRE D'IONS LOURDS ET MOMENTS ANGULAIRES COMPLEXES. Colloquium on Nuclear Surface, 1975, Dijon, France. pp.C5-110-C5-110, 10.1051/jphyscol:1975525 . jpa-00216380

\section{HAL Id: jpa-00216380 https://hal.science/jpa-00216380}

Submitted on 1 Jan 1975

HAL is a multi-disciplinary open access archive for the deposit and dissemination of scientific research documents, whether they are published or not. The documents may come from teaching and research institutions in France or abroad, or from public or private research centers.
L'archive ouverte pluridisciplinaire HAL, est destinée au dépôt et à la diffusion de documents scientifiques de niveau recherche, publiés ou non, émanant des établissements d'enseignement et de recherche français ou étrangers, des laboratoires publics ou privés. 


\title{
DIFFUSION AVANT ET ARRIËRE D'IONS LOURDS ET MOMENTS ANGULAIRES COMPLEXES
}

\author{
N. ROWLEY et C. MARTY \\ Institut de Physique Nucléaire, Division de Physique Théorique (*), 91406 Orsay, France
}

\begin{abstract}
Résumé.-- L'amplitude de diffusion élastique d'ions lourds a été calculée par la formule de sommation de Poisson [1]. Celle-ci nécessite l'évaluation d'intégrales $I_{m}^{ \pm}(\theta)$, où $\theta$ est l'angle de diffusion et $m=0, \pm 1, \pm 2, \ldots$ A l'approximation semi-classique $I_{m}^{ \pm}(\theta)=0$ pour $m<0$. Il est préférable de calculer $I_{m}^{ \pm}$en déformant le contour d'intégration dans le plan complexe du moment angulaire. On montre alors [3], pour des paramètres de Sommerfeld grands $(\eta \gtrsim 20)$, que $I_{0}^{+}$et $I_{m}^{ \pm}, m>0$, bien que non nulles sont négligeables. En appliquant la méthode du col (déjà utilisée par Knoll et Schaeffer [2] dans un problème similaire) pour les intégrales restantes, on vérifie que seule $I_{0}^{-}$contribue aux petits angles. Elle comporte deux parties l'une liée à un col sous l'axe réel, dépendant de l'angle de diffusion, l'autre à un pôle ou à un col très localisé dans le premier quadrant du plan complexe. Les oscillations de la section efficace élastique aux angles avant résultent de l'interférence de ces deux contributions de $I_{0}^{-}$.

Vers l'arrière d'autres oscillations apparaissent dues à un col de $I_{0}^{-}$et $I_{-1}^{+}$. Si le premier terme est bien connu, le second n'existe pas à l'approximation semi-classique, car la fonction de déflexion ne peut être supérieure à $180^{\circ}$. La présence de $I_{-1}^{+}$est cependant indispensable pour reproduire l'effet glory.

Ces résultats ne dépendent pratiquement pas de la paramétrisation choisie. Ils ne sont fonction que des caractéristiques de la coupure des ondes partielles les plus basses, en particulier du moment angulaire d'affieurement.
\end{abstract}

\begin{abstract}
The heavy-ion elastic scattering amplitude has been calculated using the Poisson summation formula [1]. This involves the evaluation of certain integrals $I_{m}^{ \pm}(\theta)$, where $\theta$ is the scattering angle and $m=0, \pm 1, \pm 2, \ldots$ In the semiclassical approximation $I_{m}^{ \pm}=0$ for $m<0$. It is preferable to calculate $I_{m}^{ \pm}$by deforming the integration contour in the complex angular momentum plane. One can thus show [3] that for large Sommerfeld parameters $(n \gtrsim 20) I_{0}^{+}$and $I_{m}^{ \pm}, m>0$, although not zero, are negligible. By applying the saddle-point method (previously used by Knoll and Schaeffer [2] in a similar problem) to the remaining integrals one shows that only $I_{0}^{-}$contributes at small angles. This term consists of two parts, one related to a saddle point below the real axis whose position depends on the scattering angle and the other related to a pole or to a very localised saddle in the first quadrant of the complex plane. The oscillations in the forward angle cross section are the result of the interference between these two contributions to $I_{0}^{-}$.

At large angles other oscillations appear due to the saddles of $I_{0}^{-}$and $I_{-1}^{+}$. Although the first term is well known the second does not exist in the semiclassical approximation since the deflection function cannot be greater than $180^{\circ}$. The presence of $I_{-1}^{+}$is indispensable if one is to reproduce the glory effect.

These results are practically independent of the parametrisation chosen. They are a function only of the characteristics of the cutoff of the low partial waves, in particular of the critical angular momentum.
\end{abstract}

\section{Bibliographie}

[1] Berry, M. V., Proc. Phys. Soc. 89 (1966) 479.

[2] KNOLl, J., SChaeffer, R., Phys. Lett. 52B (1974) 131.

[3] Rowley, N., Marty, C., Phys. Lett. 55B (1975) 430.

(*) Laboratoire associé au C.N.R.S. 